\title{
Purification and Some Properties of a Thermostable Metal Proteinase Produced by Thermomicrobium sp. KN-22 Strain
}

\author{
Sawao Murao, Yoshiyuki Nomura, Katashi Nagamatsu, Kazuo Hirayama, \\ Masayoshi IwaHARA and Takashi SHIN \\ Department of Applied Microbial Technology, The Kumamoto Institute of Technology, \\ Kumamoto 860, Japan \\ Received December 10, 1990
}

\begin{abstract}
A extreme thermophile that produces a heat-stable proteinase was isolated from hot-spring water and classified as Thermomicrobium sp. KN-22 (growth temperature, $50-83^{\circ} \mathrm{C}$; and optimum growth temperature, $70^{\circ} \mathrm{C}$ ). The proteinase was purified from the culture broth of this strain by fractionation with ammonium sulfate, chromatography on columns of DEAE-cellulose and CM-Sepharose CL-6B, and HPLC on TSKgel CM-5PW. The purified enzyme gave a single band on SDS-polyacrylamide gel electrophoresis and a single peak after HPLC (yield 8.8\%). The enzyme had maximum activity at $\mathrm{pH} 8.5$ and at $75^{\circ} \mathrm{C}$ and it was stable up to $60^{\circ} \mathrm{C}$. The molecular weight of the enzyme was 35,000 by SDS-PAGE. Since the enzymatic activity was completely inhibited by EDTA, $o$-phenanthroline, and phosphoramidon, it appears that the enzyme is a metal proteinase.
\end{abstract}

Generally, enzymes are unstable to heat, and the purification and storage of an enzyme should be done at low temperature. Since enzymes produced by thermophiles are more thermostable than those produced by mesophiles, enzymes from thermophiles are stable at room temperature for long periods of time. Therefore, enzymes produced by thermophiles have been developed as reagents for clinical analyses. With respect to proteinases produced by extreme thermophiles, only a few enzymes, namely, caldolysin, ${ }^{1)}$ aqualysin, ${ }^{2)}$ and archaelysin, ${ }^{3)}$ have been reported. We have been searching for novel thermostable proteinases, and we have already reported a thermostable acid proteinase ${ }^{4)}$ produced by a moderate thermophile.

Now we report some taxonomic properties of an extreme thermophile, and the purification and some properties of a proteinase produced by this microorganism are described.

\section{Materials and Methods}

Reagents. DEAE-cellulose was obtained from Wako Pure
Chemical Industries, Ltd. CM-Sepharose CL-6B was purchased from Pharmacia. TSKgel CM-5PW was from Tosoh Co. Casein (Hammarsten) was from Merck. Polypeptone and yeast extract were obtained from Wako Pure Chemical Industries, Ltd. Agar (HM-8) was from Ina Food Industries $\mathrm{Co}$. All other chemicals were of analytical grade and obtained from commercial sources.

Isolation of microorganisms. The compositions of the media used for isolation of strains are shown in Table I. Samples of water and mud from hot springs were cultured in rich medium at above $75^{\circ} \mathrm{C}$ (medium $\mathrm{A}$ or $\mathrm{B}$ in Table I). Then microorganisms were cultured on an agar medium with casein (medium $\mathrm{C}$ in Table I) at temperatures above

Table I. Media for Screening

\begin{tabular}{lllc}
\hline A Glucose & $1.0 \mathrm{~g} / \mathrm{l}$ Casein Na & $5.0 \mathrm{~g} / \mathrm{l}$ \\
Polypeptone & 1.0 & Soluble starch & 10.0 \\
Yeast extract & 1.0 & Yeast extract & 1.0 \\
Hot-spring water & 1.01 & $\mathrm{KH}_{2} \mathrm{PO}_{4}$ & 1.0 \\
& & $\mathrm{MgSO}_{4} \cdot 7 \mathrm{H}_{2} \mathrm{O}$ & 0.5 \\
$\mathrm{~B} \mathrm{Glucose}$ & $1.0 \mathrm{~g} / \mathrm{l}$ & $\mathrm{CaCl}_{2}$ & 1.0 \\
Yeast extract & 1.0 & $\mathrm{FeSO}_{4} \cdot 6 \mathrm{H}_{2} \mathrm{O}$ & $10.0 \mathrm{mg}$ \\
$\mathrm{MgSO}_{4} \cdot 7 \mathrm{H}_{2} \mathrm{O}$ & 1.0 & $\mathrm{ZnSO}_{4} \cdot 7 \mathrm{H}_{2} \mathrm{O}$ & 1.0 \\
$\mathrm{KH}_{2} \mathrm{PO}_{4}$ & 1.0 & $\mathrm{CuSO}_{4} \cdot 7 \mathrm{H}_{2} \mathrm{O}$ & 1.0 \\
$\mathrm{Hot}_{\text {Hopring water }}$ & 1.01 & $\mathrm{MnSO}_{4} \cdot 4 \mathrm{H}_{2} \mathrm{O}$ & 1.0 \\
& & $\mathrm{Agar} \mathrm{HM}-8)$ & $20.0 \mathrm{~g}$ \\
& & pH 7.0 & \\
\hline
\end{tabular}


$75^{\circ} \mathrm{C}$. Colonies with halos as a result of caseinolytic activity were selected as proteinase-producing microorganisms.

Identification of microorganisms. Tests of assimilation of glucose and starch were done by the method of lizuka and Komagata. ${ }^{5)}$ Gram staining was done by a modification of the method of Hucker. ${ }^{6)}$ The composition of the cell wall was analyzed by the method of Komagata. ${ }^{7}$ Identification was made by reference to descriptions in Bergey's Manual of Determinative Bacteriology. ${ }^{8}$

Cultivation. Thermomicrobium sp. KN-22 strain, after isolation, was cultured in medium with the following constituents: soluble starch, $20 \mathrm{~g}$; polypeptone, $20 \mathrm{~g}$; yeast extract, $2 \mathrm{~g} ; \mathrm{KH}_{2} \mathrm{PO}_{4}, 1 \mathrm{~g} ; \mathrm{MgSO}_{4} \cdot 7 \mathrm{H}_{2} \mathrm{O}, 0.5 \mathrm{~g} ; \mathrm{CaCl}_{2}$. $2 \mathrm{H}_{2} \mathrm{O}, 1.5 \mathrm{~g} ; \mathrm{FeSO}_{4} \cdot 6 \mathrm{H}_{2} \mathrm{O}, 10 \mathrm{mg} ; \mathrm{ZnSO}_{4} \cdot 7 \mathrm{H}_{2} \mathrm{O}, 1 \mathrm{mg}$, $\mathrm{CuSO}_{4} \cdot 5 \mathrm{H}_{2} \mathrm{O}, 1 \mathrm{mg}$; and $\mathrm{MnSO}_{4} \cdot 4 \mathrm{H}_{2} \mathrm{O}, 1 \mathrm{mg}$ in $1000 \mathrm{ml}$ of tap water, $\mathrm{pH}$ 7.0. Medium for stock cultures included $2 \%$ HM-8 agar in the above medium. Strain KN-22 was inoculated from a stock culture on an agar slant and cultured at $70^{\circ} \mathrm{C}$ for $20 \mathrm{hr}$. A loopful of cells grown on the agar slant was inoculated into a test tube (diameter $20 \mathrm{~mm}$ ) which contained $8 \mathrm{ml}$ of medium and was cultured at $70^{\circ} \mathrm{C}$ for $3-5 \mathrm{hr}$ on a reciprocal shaker $(120$ strokes per min; seed culture). For production of the proteinase, a 2-liter miniature fermentor (MB type; Iwashiya BioScience Co., Ltd.) containing 11 of the medium was used with an air flow of $1.41 / \mathrm{min}$ and agitation at $700 \mathrm{rpm}$. A sample of seed culture, equivalent to $5 \%$ of the volume of the culture, was inoculated for production of the proteinase. After $14 \mathrm{hr}$ of cultivation, as maximum proteolytic activity was obtained $(5.0 \mathrm{unit} / \mathrm{ml})$, the culture broth was used as a source for the enzyme.

Measurement of proteolytic activity. Proteolytic activity was measured by the method of Hagihara et al. ${ }^{9)}$ One unit of enzymatic activity was defined as the amount of enzyme that caused an increase in absorbance at $660 \mathrm{~nm}$ of $1.0 \mathrm{in}$ $10 \mathrm{~min}$. In the experiments on optimum $\mathrm{pH}$ and $\mathrm{pH}$ stability of the enzyme, the following buffer solutions containing $5 \mathrm{mM} \mathrm{CaCl}_{2}$ were used: $0.1 \mathrm{M}$ citrate- $\mathrm{NaOH}$ buffer $(\mathrm{pH}$ 3-5), $0.1 \mathrm{~m}$ maleate-Tris- $\mathrm{NaOH}$ buffer ( $\mathrm{pH}$ 6-7), $0.1 \mathrm{M}$ Tris- $\mathrm{HCl}$ buffer ( $\mathrm{pH} 8-9$ ), and $0.1 \mathrm{M}$ glycine- $\mathrm{NaOH}$ buffer $(\mathrm{pH} 10-12)$. The enzymatic reaction was done at various $\mathrm{pHs}$ for $10 \mathrm{~min}$ at $70^{\circ} \mathrm{C}$. In the experiments on $\mathrm{pH}$ stability, the solution of enzyme was kept at $25^{\circ} \mathrm{C}$ for $24 \mathrm{hr}$ at various $\mathrm{pH}$ and residual activity was measured at $\mathrm{pH} 8.0$

Measurement of protein. Protein was measured from the absorbance at $280 \mathrm{~nm}$

Gel electrophoresis. Sodium dodecyl sulfate-polyacrylamide gel electrophoresis (SDS-PAGE) was done by the method of Laemmli. ${ }^{10)}$

Amino acid composition. The sample (total $A_{280}=0.11$ ) was dissolved in $3 \mathrm{ml}$ of distilled water and the solution was evaporated to dryness. The dry matter was hydrolyzed with constant boiling $\mathrm{HCl}$ in a sealed tube at $110^{\circ} \mathrm{C}$ for $48 \mathrm{hr}$ in vacuo. The resultant mixture was evaporated to dryness, and distilled water was added to the residue and the mixture again evaporated to dryness. This operation was done five times. The resultant amino acids were analyzed by an automatic amino acid analyzer (Hitachi model L-8500).

Hydrolysis of oxidized insulin $B$ chain by proteinase from strain $K N-22$. The reaction mixture contained $150 \mu \mathrm{g}$ of oxidized insulin $\mathrm{B}$ chain and $14.5 \mathrm{ng}$ of the proteinase in $325 \mu 1$ of $50 \mathrm{~mm}$ Tris $-\mathrm{HCl}$ buffer $(\mathrm{pH} 8.0$ ). The reaction was done at $37^{\circ} \mathrm{C}$ for $40 \mathrm{~min}$ and analyses were done by HPLC on a column of Nucleosil ${ }_{5} \mathrm{C}_{18}(4 \mathrm{~mm}$ i.d. $\times 150$ $\mathrm{mm})$. The peptides were eluted with a linear gradient, $0.05 \%$ trifluoroacetic acid to $40 \%$ acetonitrile $/ 0.05 \%$ trifluoroacetic acid, for $45 \mathrm{~min}$ at a flow rate of $0.8 \mathrm{ml} / \mathrm{min}$.

Separation of hydrolysate of oxidized insulin B chain. The reaction mixture contained $4 \mathrm{mg}$ of oxidized insulin $B$ chain and $0.4 \mu \mathrm{g}$ of the enzyme in $2 \mathrm{ml}$ of $50 \mathrm{~mm}$ Tris- $\mathrm{HCl}$ buffer (pH 8.0). The reaction was done at $37^{\circ} \mathrm{C}$ for $1 \mathrm{hr}$ and the hydrolysis products were isolated as pure samples by HPLC on a column of Nucleosil ${ }_{10} \mathrm{C}_{18}(8 \mathrm{~mm}$ i.d. $\times 150 \mathrm{~mm})$. The elution of the peptides was the same as above mentioned except for the flow rate $(3 \mathrm{ml} / \mathrm{min})$. The isolated samples were lyophilized and used for analysis of amino acid composition.

\section{Results}

\section{Isolation of the microorganism}

As mentioned in Materials and Methods, strain $\mathrm{KN}-22$ was isolated. The bacteria were rod-shaped (length, $\sim 7 \mu \mathrm{m}$; width, $\sim 2 \mu \mathrm{m}$ ); they grew under aerobic conditions and produced yellow pigment. The optimum temperature and $\mathrm{pH}$ for growth of this microorganism were $70^{\circ} \mathrm{C}$ (growth temperature, $50-83^{\circ} \mathrm{C}$ ) and 7.0 (range of $\mathrm{pH}$ values, 6.0 $9.0)$, respectively.

\section{Identification of the microorganism}

Strain KN-22 could not assimilate glucose but could assimilate starch. Gram staining was negative. Catalase and oxidase tests were both positive. This strain was non-motile. Mesodiaminopimelic acid, alanine, and glutamic acid were detected as cell wall constituents, but no reducing sugars were detected in the cell wall. According to the taxonomic criteria in 
Bergey's Manual of Determinative Bacteriology, ${ }^{8)}$ only two genera, Thermus and Thermomicrobium, are described as Gram-negative aerobes with an optimum growth temperature of $70-75^{\circ} \mathrm{C}$. However, Thermus can assimilate glucose, while strain $\mathrm{KN}-22$ could not. Strain $\mathrm{KN}-22$ was allocated to the genus Thermomicrobium from its physiological properties, so it was concluded that strain $\mathrm{KN}-22$ should be identified as a member of this genus.

\section{Purification of the enzyme}

The entire purification was done at room temperature. The culture broth was centrifuged at $7,000 \times g$ for $15 \mathrm{~min}$. The supernatant from the culture broth $(10.41)$ was adjusted to $\mathrm{pH}$ 8.0 , and then it was concentrated about 3 -fold at $40^{\circ} \mathrm{C}$ under reduced pressure. After concentration of the supernatant, the $\mathrm{pH}$ of the solution was again adjusted to 8.0 , and then the clear supernatant was brought to $80 \%$ saturation by addition of solid ammonium sulfate in an ice bath. After standing for 2 days, the solution was centrifuged at $7,000 \times g$ for $5 \mathrm{~min}$; the precipitate was collected and dissolved with a small amount of $20 \mathrm{~mm}$ Tris- $\mathrm{HCl}$ buffer ( $\mathrm{pH} 8.0$ ) containing $5 \mathrm{~mm}$ $\mathrm{CaCl}_{2}$. The solution was dialyzed against the same buffer. The insoluble precipitate was removed by centrifugation, and the supernatant was used as the selution of crude enzyme.

The solution of crude enzyme was put on a column of DEAE-cellulose $(2.5 \mathrm{~cm}$ i.d. $\times 40 \mathrm{~cm})$ which had been equilibrated with $20 \mathrm{~mm}$ Tris- $\mathrm{HCl}$ buffer ( $\mathrm{pH} 8.0$ ) containing $5 \mathrm{mM}$ $\mathrm{CaCl}_{2}$. The enzyme was not adsorbed. Then the flow-through fraction was dialyzed against
$10 \mathrm{~mm}$ Tris- $\mathrm{HCl}$ buffer (pH 7.5) containing $5 \mathrm{mM} \mathrm{CaCl} 2$ and put on a column of CMSepharose CL-6B $(5 \mathrm{~cm}$ i.d. $\times 15 \mathrm{~cm})$ which had been equilibrated with the same buffer. After the column had been washed with the same buffer, adsorbed materials were eluted by a linear gradient of $\mathrm{NaCl}$ from 0.0 to $0.5 \mathrm{M}$ in the same buffer. The fraction with the enzyme activity was eluted by $0.2 \mathrm{M} \mathrm{NaCl}$. The active fraction was dialyzed against $10 \mathrm{~mm}$ Tris- $\mathrm{HCl}$ buffer ( $\mathrm{pH} 7.5$ ) containing $5 \mathrm{mM} \mathrm{CaCl}$, and the enzyme was fractionated by preparative HPLC on a column of TSKgel CM-5PW $(16 \mathrm{~mm}$ i.e. $\times 10 \mathrm{~cm})$. The active fraction was eluted by $0.2 \mathrm{M} \mathrm{NaCl}$ in good agreement with the peak of protein. Active fractions were pooled as purified enzyme. Approximately 3890 -fold purification was achieved with an overall yield of $8.8 \%$ from the crude enzyme. The details of the purification are summarized in Table II.

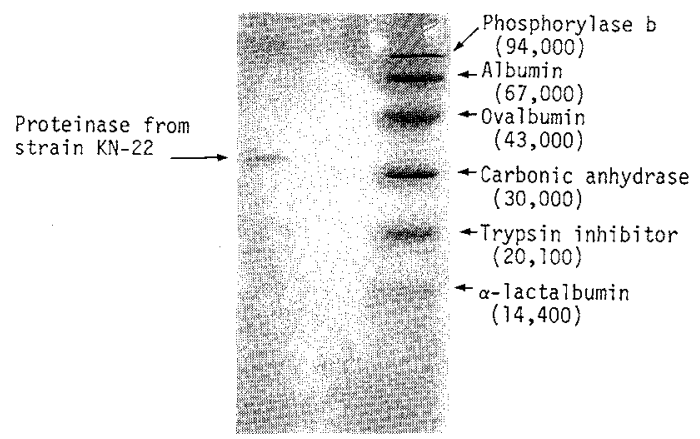

Fig. 1. SDS-Polyacrylamide Gel Electrophoresis Electrophoresis was done on a $12 \%$ gel at $\mathrm{pH} 8.8$. The protein (about $30 \mu \mathrm{g}$ ) was stained with Coomassie Brilliant Blue R-250. Marker proteins are included for comparison of mobilities. Numerals in parentheses show molecular weights of marker proteins.

Table II. Summary of PURIfication of Proteinase from Strain kn-22

\begin{tabular}{lccccc}
\hline & $\begin{array}{c}\text { Volume } \\
(\mathrm{ml})\end{array}$ & $\begin{array}{c}\text { Total activity } \\
\text { (units) }\end{array}$ & $\begin{array}{c}\text { Total protein } \\
(\mathrm{mg})\end{array}$ & $\begin{array}{c}\text { Specific activity } \\
(\mathrm{U} / \mathrm{mg})\end{array}$ & $\begin{array}{c}\text { Yield } \\
(\%)\end{array}$ \\
\hline Culture filtrate & 10,400 & 48,000 & 390,000 & 0.12 & 100 \\
$\left(\mathrm{NH}_{4}\right)_{2} \mathrm{SO}_{4}$ ppt. & 327 & 38,000 & 65,700 & 0.56 & 79 \\
DEAE-Cellulose & 2,115 & 16,100 & 306 & 52.6 & 34 \\
CM-Sepharose CL-6B & 315 & 10,800 & 48 & 225 & 22 \\
TSKgel CM-5PW & 72 & 4,200 & 9 & 467 & 8.8 \\
\hline
\end{tabular}


Criteria of purity and molecular weight

The homogeneity of the purified enzyme was examined by SDS-PAGE and HPLC. SDSPAGE was done, and protein was stained with Coomassie Brilliant Blue R-250. As shown in Fig. 1, the pruified enzyme gave a single band after electrophoresis, and a single peak after HPLC. The molecular weight of the purified

Table III. Amino Acid Composition of the PURIFIED Proteinase

\begin{tabular}{lc}
\hline Amino acid & Nearest integer $^{a}$ \\
\hline Asp & 45 \\
Thr & 18 \\
Ser & 27 \\
Glu & 21 \\
Pro & 6 \\
Gly & 45 \\
Ala & 30 \\
Cys & ND \\
Val & 21 \\
Met & 3 \\
Ile & 12 \\
Leu & 15 \\
Tyr & 30 \\
Phe & 12 \\
Lys & 9 \\
His & 6 \\
Arg & 12 \\
Trp & ND \\
\hline
\end{tabular}

a The nearest integer was calculated on the assumption that the molecular weight was 35,000 .

$b$ ND, not determined.

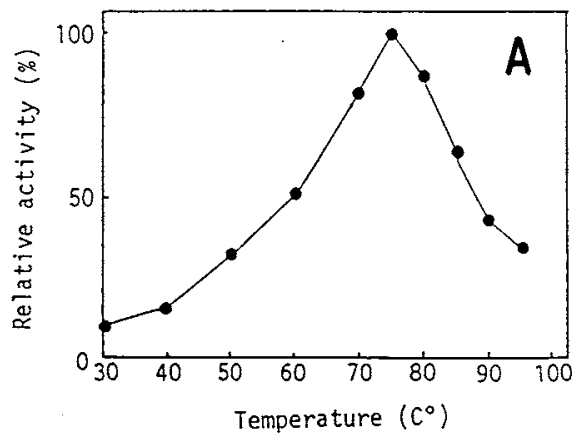

enzyme was 35,000 by SDS-PAGE and 10,300 by chromatography on TSKgel G2000SW.

\section{Amino acid composition}

The amino acid composition of the purified proteinase from KN-22 is shown in Table III. Aspartic acid (including asparagine) and glycine residues were abundant in the enzyme molecule.

Effects of $\mathrm{pH}$ and temperature on the activity and stability of the proteinase from $K N-22$ strain

The optimum $\mathrm{pH}$ for enzymatic activity was $8-9$, and the enzyme was stable from $\mathrm{pH} 6.0$ up to $\mathrm{pH} 11.0$ (data not shown). As shown in Fig. 2, the optimum temperature of the enzyme was $75^{\circ} \mathrm{C}(\mathrm{A})$, and the enzymatic activity was stable up to $60^{\circ} \mathrm{C}$ (B). However, the thermostability of the purified enzyme was lower than that of the crude enzyme, as discussed below.

Effects of some reagents on the enzymatic activity

Various reagents such as ethylenediaminetetraacetic acid (EDTA), phosphoramidon, ophenanthroline, phenylmethylsulfonyl fluoride, Streptomyces subtilisin inhibitor, and antipain in $1.9 \mathrm{ml}$ of solution were incubated at $70^{\circ} \mathrm{C}$ for $10 \mathrm{~min}$, and then $0.1 \mathrm{ml}$ of the solution of enzyme was added and the mixture in-

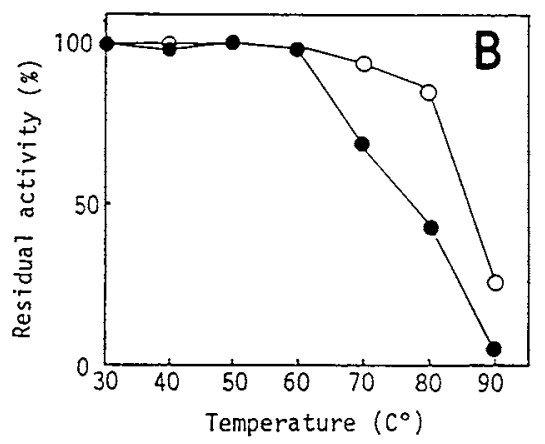

Fig. 2. Effects of Temperature on the Activity and Stability of the Purified Enzyme.

A: Optimum temperature, B: thermostability.

The enzymatic reaction was done at various temperatures for $10 \mathrm{~min}$ ( $\mathrm{pH} 8.0$ ) (graph A). The solution of enzyme was heated at various temperatures for $10 \mathrm{~min}(\mathrm{pH} 8.0)$ and residual activity was measured at $\mathrm{pH}$ 8.0 for $10 \mathrm{~min}\left(70^{\circ} \mathrm{C}\right)$ (graph $\left.\mathrm{B}\right)$.

, Purified enzyme; $O$, crude enzyme (graph B). 


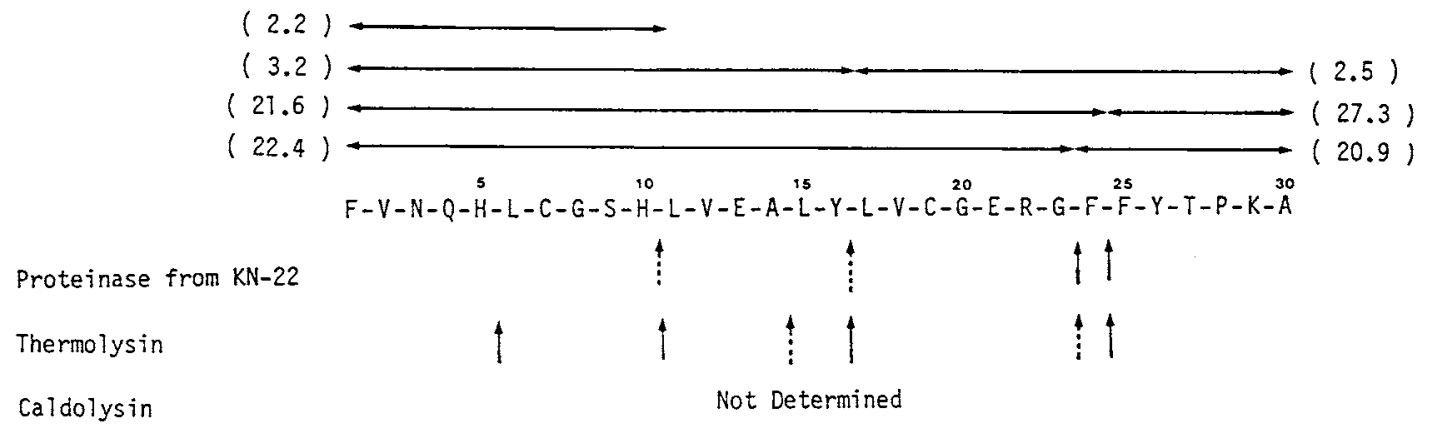

Fig. 3. Cleavage Sites for Hydrolysis of Oxidized Insulin B Chain by the Purified Enzyme.

Vertical arrows show cleavage sites for hydrolysis. Arrows with solid line indicate first attack sites, and those with broken line indicate minor sites. Arrows written sideways indicate peptides obtained by hydrolysis of oxidized insulin B chain. The values in parentheses are yield (\%) of peptides of oxidized insulin B chain obtained after 1 hr of incubation with $\mathrm{KN}-22$ proteinase.

cubated at $70^{\circ} \mathrm{C}$ for $30 \mathrm{~min}(\mathrm{pH} 8.0)$. Samples of the mixture $(0.5 \mathrm{ml})$ were used as the solution of enzyme. The enzyme activity was inhibited by specific inhibitors of metal proteinases, EDTA (1.0 mM), phosphoramidon $(0.1 \mathrm{~mm})$, and $o$-phenanthroline $(1.0 \mathrm{~mm})$ by $84.7,99.1$, and $98 \%$, respectively. Other reagents did not inhibit the enzymatic activity. Therefore, it appears that the purified enzyme was a metal proteinase.

The cleavage sites of hydrolysis for oxidized insulin $B$ chain by proteinase from strain $K N-22$

The hydrolysis products for oxidized insulin $B$ chain by the enzyme included 7 peptides. The resultants were isolated as pure samples and their amino acid compositions were analyzed. The yields of peptides corresponding to $\mathrm{Phe}^{25}-\mathrm{Ala}^{30}, \mathrm{Phe}^{1}{ }^{1-\mathrm{Gly}^{23}}{ }^{2} \mathrm{Phe}^{1}-\mathrm{Phe}^{24}, \mathrm{Phe}^{24}-$ $\mathrm{Ala}^{30}, \mathrm{Phe}^{1}-\mathrm{Tyr}^{16}{ }^{16} \mathrm{Leu}^{17}-\mathrm{Ala}^{30}$, and $\mathrm{Phe}^{1}$ $\mathrm{His}^{10}$ were $27.3,22.4,21.6,20.9,3.2,2.5$, and $2.2 \%$, respectively. Judging from the course of the hydrolysis and the yields of peptides, the peptide bonds of $\mathrm{Gly}^{23}-\mathrm{Phe}^{24}$ and $\mathrm{Phe}^{24}$ $\mathrm{Phe}^{25}$ were hydrolyzed preferentially and then the peptide bonds of $\mathrm{His}^{10}{ }^{10} \mathrm{Leu}^{11}$ and $\mathrm{Tyr}^{16}$. $\mathrm{Leu}^{17}$ were hydrolyzed in succession. Therefore, the cleavage sites of hydrolysis for oxidized insulin $B$ chain by the enzyme were decided as in Fig. 3, including cleavage sites of other thermostable metal proteinases. The specificity of the enzyme for the substrate is broad, resembling other microbial metal proteinases.

\section{Discussion}

With respect to metal proteinase produced by extreme thermophiles, only one example, caldolysin, ${ }^{1)}$ has been reported. Caldolysin is not inhibited by $10 \mathrm{~mm}$ o-phenanthroline (zinc-specific chelator) and was inhibited by $1 \mathrm{~mm}$ EDTA and $10 \mathrm{mM}$ EGTA (calciumspecific chelators), $40 \%$ and $45 \%$, respectively. As to this phenomenon, Cowan and Daniel assumed the following: (a) caldolysin contains no essential zinc ion cofactor or (b) any zinc atom present was inaccessible or too tightly bound to be chelated and (c) calcium was important for the maintenance of molecular integrity. By contrast, the proteinase from KN-22 was completely inhibited by EDTA and $o$-phenanthroline. The molecular weights of the proteinase from $\mathrm{KN}-22$ and caldolysin are 35,000 (SDS-PAGE) and 21,000, respectively. Therefore, the proteinase from $\mathrm{KN}-22$ is different from caldolysin.

Thermolysin, produced by a mesothermophile (Bacillus thermoproteolyticus), is completely inhibited by phosphoramidon at a molar ratio of one to one. However, as shown in Fig. 4, 50\% inhibition of activity of the proteinase from $\mathrm{KN}-22(0.14 \mathrm{nmol})$ occurred 


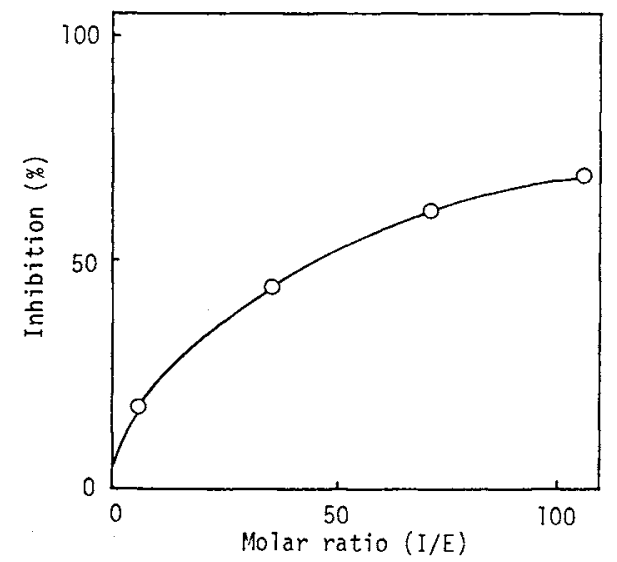

Fig. 4. Inhibition of the Purified Enzyme by Phosphoramidon.

The enzyme was incubated at $70^{\circ} \mathrm{C}$ for $30 \mathrm{~min}$ with phosphoramidon at $\mathrm{pH} 8.0$ and the residual activity was measured at $70^{\circ} \mathrm{C}$. I indicates inhibitor (phosphoramidon), and $E$ indicates the purified enzyme.

with addition of $6.16 \mathrm{nmol}$ phosphoramidon (molar ratio of one to forty-four of the enzyme to the reagent), and the affinity of the enzyme to phosphoramidon was low, as compared with that of thermolysin. Thus, the proteinase from $\mathrm{KN}-22$ is clearly different from thermolysin.

The molecular weight of the proteinase from KN-22 was 35,000 by SDS-PAGE and 10,300 by gel filtration with TSKgel G2000SW. Furthermore, the enzyme was filtrable through an ultrafiltration membrane (UF-10PS; Tosoh Co.; molecular size cut off, 10,000 daltons). These results suggest that the enzyme has a rather complex tertiary structure (e.g., rod shaped) in solution.

Generally, enzymes produced by extreme thermophiles are thermostable, for example, caldolysin is stable to heating at $85^{\circ} \mathrm{C}$ for 11 hr. By contrast, the thermostability of the proteinase from $\mathrm{KN}-22$ was almost the same as that of proteinases from mesophiles, even though it was produced by an extreme thermophile, Thermomicrobium sp. The temperature at which $50 \%$ of the activity was destroyed by heating for $10 \mathrm{~min}$, was about $15^{\circ} \mathrm{C}$ lower than that for the crude enzyme. Therefore, we followed the thermostability of the proteinase through the purification procedure. After the solution of crude enzyme was put on the column of DEAE-cellulose, its thermostability apparently decreased. Therefore, some material that was adsorbed to DEAE-cellulose may participate in the thermostability of the proteinase. The column of DEAE-cellulose was eluted by a linear gradient of $\mathrm{NaCl}$ from 0.0 to $1.0 \mathrm{M}$. When dialyzed fractions from the column were added to the purified proteinase, the thermostability of the enzyme returned to the original level. Further investigations of this phenomenon are now in progress. The results will be reported elsewhere.

\section{References}

1) D. A. Cowan and R. M. Daniel, Biochim. Biophys. Acta, 705, 293 (1982).

2) H. Matsuzawa, K. Tokugawa, M. Hamaoki, M. Mizoguchi, H. Taguchi, I. Terada, S. T. Kwon and T. Ohta, Eur. J. Biochem., 171, 441 (1988).

3) D. A. Cowan, K. A. Smolenski, R. M. Daniel and H. W. Morgan, Biochem. J., 247, 121 (1987).

4) S. Murao, K. Ohkuni, M. Nagao and T. Shin, Agric. Biol. Chem., 52, 1629 (1988).

5) H. Iizuka and K. Komagata, Nippon Nōgeikagaku Kaishi, 36, 668 (1962)

6) T. Hasegawa Ed., "Biseibutsu no Bunrui to Dotei," Tokyo Daigaku Shuppan Kai, 1975.

7) K. Komagata Ed., "Biseibutsu no Kagakubunrui Jikkenho," Gakkai Shuppan Center, 1982.

8) R. E. Buchanan and N. E. Gibbons, "Bergey's Manual of Determinative Bacteriology," 8th Ed., The Williams and Wilkins Co., Baltimore, 1975.

9) B. Hagihara, H. Matsubara, M. Nakai and K. Okunuki, J. Biochem., (Tokyo), 45, 185 (1958).

10) U. K. Laemmli, Nature, 227, 680 (1970). 